\title{
A comparative study of low dose Bupivacaine vs high dose Bupivacaine along with Fentanyl and Phenylephrine on Pregnant women undergoing elective Caesarean Section under Spinal Anesthesia
}

\author{
A Sivaram ${ }^{1}$, Govardhani $Y^{2}$, Varaprasad U S S A ${ }^{3}$ \\ ${ }^{1}$ Post graduate Student, ${ }^{2}$ Senior resident, ${ }^{3}$ Professor. All are affiliated with Department of Anesthesiology \& Intensive Care, \\ Dr Pinnamaneni Siddhardha Institute of Medical Sciences, Chinaoutpalli, Krishna District, A P, INDIA
}

Corresponding author: Dr. A Sivaram, Email: drsivaram79@gmail.com

\begin{abstract}
Background: This randomized study was conducted to evaluate the effect of low dose vs high dose Bupivacaine + Fentanyl, with or without Phenylephrine infusion on hemodynamics, motor recovery, adequacy of block and side effects, on pregnant women undergoing caesarean section under spinal anaesthesia. Methods: One hundred sixty pregnant women were randomized into four groups of fourty each. Group-A $(\mathrm{n}=40)$ received $10 \mathrm{mg}(2 \mathrm{ml})$ of Bupivacaine + Fentanyl $25 \mu \mathrm{g}(0.5 \mathrm{ml})$ along with Phenylephrine i.v. infusion of $0.25 \mu \mathrm{g} / \mathrm{Kg} / \mathrm{min}$. Group-B $(\mathrm{n}=40)$ recieved same drugs, without Phenylephrine infusion. Group-C $(\mathrm{n}=40)$ received $7 \mathrm{mg}(1.4 \mathrm{ml})$ of Bupivacaine+Fentanyl $25 \mu \mathrm{g}(0.5 \mathrm{ml})$ along with Phenylephrine i.v. infusion of $0.25 \mu \mathrm{g} / \mathrm{Kg} / \mathrm{min}$. Group-D $(\mathrm{n}=4)$ received same drugs, without Phenylephrine infusion. Result: When given with fentanyl, low dose bupivacaine $(1.4 \mathrm{ml} / 7 \mathrm{mg}$ ) was as effective as of high dose buypivacaine $(2 \mathrm{ml} / 10 \mathrm{mg})$ in $\mathrm{producing}$ adequate relaxation and analgesia. Addition of low dose phenylephrine infusion decreased the incidence of hypotension maintains the pulse rate nearer to baseline for better hemodynamic stability. The motor recovery was quick in case of low dose bupivacaine groups with or without phenylephrine which aids in early mobilization of pregnant women. Conclusion: When given along with an opioid like fentanyl, low dose bupivacaine $(1.4 \mathrm{ml} / 7 \mathrm{mg}$ ) was as effective as of high dose buypivacaine $(2 \mathrm{ml} / 10 \mathrm{mg})$ in producing adequate relaxation and analgesia. Addition of low dose phenylephrine infusion decreased the incidence of hypotension and maintained better hemodynamic stability
\end{abstract}

Key words: Bupivacaine, Fentanyl, Phenylephrine infusion, caesarean section, hemodynamic stability

\section{Introduction}

Prevention of hemodynamic instability during lower segment caesarean section under spinal anesthesia has been the aim of several studies. Non invasive monitoring has been used in previous studies but spinal anesthesia for caesarean section has become popular in recent decade \& it has been the preferred technique for the majority of anesthesiologist. This is primarily due to increased maternal mortality with general anesthesia and benefits conveyed to the mother. But, spinal anesthesia is associated with major or minor complications in the pregnant pregnant women, the commonest being maternal hypotension.

It is believed to occur in up to $95 \%$ of the pregnant women and may lead to a reduction in utero-placental perfusion resulting in fetal acid-base abnormalities [1]. Local anesthetics plus opioids administered together intrathecally have been shown to have a synergistic analgesic effect $[2,3]$. Intrathecal opioid increases the

Manuscript received: $15^{\text {th }} \mathrm{Feb} 2014$

Reviewed: $25^{\text {th }} \mathrm{Feb} 2014$

Author Corrected: $13^{\text {th }}$ Mar 2014

Accepted for Publication: $15^{\text {th }}$ Mar 2014 quality of analgesia and reduces local anesthetic requirements, with some studies showing favourable effects on haemodinamics stability [4, 5]. Therefore, it may be possible to achieve spinal anesthesia with less hypotension by using a reduced dose of local anesthetic. Opioids have been proved to give more intensity of block and quicker onset time when added as an adjunct to spinal anaesthetic without altering hemodynamic stability in pregnant women undergoing ceasarean section. Since, low dose bupivacaine will be better effective along with an opioid like fentanyl, it was added in this study in all the groups of pregnant women along with bupivacaine. Studies show the dose dependent effects of hyperbaric bupivacaine on maternal hemodynamics and showed that small dose of bupivacaine with fentanyl better preserves hemodynamic stability resulting in equally effective anaesthesia.

Phenylephrine, an alpha agonist is more prominent venoconstrictor. During caesarean sections phenylephrine maintains maternal systolic blood pressure at baseline and is associated with low incidence of fetal acidosis than that 
of ephedrine [6,7]. The aim of this randomized trial was to compare the effects of two different intrathecal doses of bupivacaine, with or without intravenous phenylephrine infusion, on cardiac output and systolic blood pressure as general anesthesia increase maternal mortality; spinal anesthesia is advantageous to pregnant mothers with fewer side effects, in the form of maternal hypotension and maintaing hemodynamic stability.

\section{Methods}

After obtaining hospital ethical committee's approval, 160 uncomplicated pregnant mothers of age between 1929 years, weighing between 55-65 Kg., height between $150-160 \mathrm{cms}$ scheduled to have caesarean section were chosen for this randomized comparative study.

Pregnant women with foetal malposition, hypertention, cardiac disease, renal disease, diabetes mellitus and on chronic medication were excluded from the study.

Informed consent was obtained, and hemodynamic variables were noted. Pregnant women were randomly divided into four groups of 40 each, without any bias.

With all aseptic precautions lumbar puncture was performed with 25G Quinke needle in L3-L4 inter space in left lateral position and group specified drugs were injected according to random assignment and pregnant women was immediately placed in supine position with a wedge under the hip.

Group-A ( $\mathrm{n}=40)$ : Received $0.5 \%$ Bupivacaine heavy $10 \mathrm{mg}(2 \mathrm{ml})$ and Fentanyl citrate $25 \mathrm{mcg}(0.5 \mathrm{ml})$ making a total of $2.5 \mathrm{ml}$, intrathecally. They also received continuous infusion of phenylepherine $0.25 \mu / \mathrm{Kg} /$ minute intravenously by separate I.V line through an infusion pump, till the end of surgery.

Group-B ( $\mathrm{n}=40)$ : Received $0.5 \%$ Bupivacaine heavy $10 \mathrm{mg}(2 \mathrm{ml})$ and Fentanyl citrate $25 \mu \mathrm{g}(0.5 \mathrm{ml})$ making a total of $2.5 \mathrm{ml}$, intrathecally, without phenylephrine infusion.

Group-C ( $\mathrm{n}=40)$ : Received $0.5 \%$ Bupivacaine heavy $7 \mathrm{mg}$ $(1.4 \mathrm{ml})$ and Fentanyl citrate $25 \mu \mathrm{g}(0.5 \mathrm{ml})$ and $0.6 \mathrm{ml}$ of normal saline making a total of $2.5 \mathrm{ml}$, intrathecally. They also received phenylepherine $0.25 \mu / \mathrm{Kg} /$ minute.

Group-D ( $\mathrm{n}=40)$ : Received $0.5 \%$ Bupivacaine heavy $7 \mathrm{mg} .(1.4 \mathrm{ml})$ and Fentanyl citrate $25 \mathrm{mcg}(0.5 \mathrm{ml})$ and without phenylephrine infusion.

All pregnant women received supplemental Oxygen of 4 $\mathrm{L} / \mathrm{min}$ via polymask. Pulse rate, SpO2, B.P (systolic, diastolic and mean) were recorded every 2 minutes till the completion of delivery of placenta and firm uterine contraction, then at every 5 minutes till the completion of surgery and thereafter at every 15 minutes, until pregnant women able to perform bilateral straight leg lift indicating complete motor recovery.

The onset of upper sensory level was noted by pinprick method 5 minutes after initiation of spinal blockade.

All the pregnant women were pre hydrated during the procedure the pregnant women received maintainance fluid of just 30 drops/min of Ringer solution, unless hypotension is warranted.

The observations and results were analysed.

\section{Results}

In this study, 160 uncomplicated pregnant women planed to undergo elective caesarean section were chosen for this randomized comparative study. The results encountered in the present study are enumerated in table 1-10

Table 1: Demographic profile of the participants of the 4-study group

\begin{tabular}{|l|l|l|l|l|}
\hline & Group A & Group B & Group C & Group D \\
\hline No. of patients & 40 & 40 & 40 & 40 \\
\hline Age in years & $25 \pm 1.39$ & $24 \pm 1.40$ & $24 \pm 1.98$ & $24 \pm 1.50$ \\
\hline Weight in Kgs & $60 \pm 6.48$ & $61 \pm 5.05$ & $60 \pm 5.62$ & $61 \pm 5.09$ \\
Height in Cms & $154 \pm 3.73$ & $154 \pm 3.38$ & $154 \pm 3.04$ & $154 \pm 3.18$ \\
\hline
\end{tabular}

Most of the pregnant women in our maternity ward, coming for elective caesarean sections are less than $160 \mathrm{~cm}$ of height and below $65 \mathrm{kgs}$ of weight. 
Table 2: level of sensory blockade and Motor blockade

\begin{tabular}{|c|c|c|c|c|}
\hline & Group A & Group C & Group C & Group D \\
\hline $\begin{array}{l}\text { - Height of Sensory Level ( } \\
\text { Median) }\end{array}$ & $\mathrm{T} 4$ [T3 - T6] & $\mathrm{T} 4$ [T3 - T6] & $\mathrm{T} 4[\mathrm{~T} 3-\mathrm{T} 6]$ & T4 [T3 - T6] \\
\hline $\begin{array}{l}\text { - Time for injection to } \\
\text { highest sensory level in } \\
\text { minutes }\end{array}$ & $5.7 \pm 1.34$ & $5.8 \pm 1.22$ & $5.8 \pm 0.98$ & $6.0 \pm 1.20$ \\
\hline $\begin{array}{l}\text { - Onset of grade } 3 \text { motor } \\
\text { block (Min) }\end{array}$ & $5.7 \pm 0.65$ & $6.0 \pm 0.79$ & $6.0 \pm 0.82$ & - $\quad \pm 0.91$ \\
\hline $\begin{array}{l}\text { - Duration of motor block } \\
\text { (Min) }\end{array}$ & $145 \pm 4.43$ & $142 \pm 4.12$ & $98 \pm 4.99$ & $101 \pm 9.11$ \\
\hline
\end{tabular}

Table 3: Baseline of Hemodynamics before starting of Anaeshesia induction

\begin{tabular}{|l|l|l|l|l|} 
& Group A & Group B & Group C & Group D \\
\hline $\begin{array}{l}\text { Systolic blood pressure } \\
(\mathrm{mmHg})\end{array}$ & $126 \pm 4.76$ & $129 \pm 4.31$ & $121 \pm 5.30$ & $124 \pm 5.68$ \\
\hline $\begin{array}{l}\text { Mean arterial pressure } \\
(\mathrm{mmHg})\end{array}$ & $92 \pm 3.78$ & $92 \pm 4.65$ & $92 \pm 7.70$ & $92 \pm 4.00$ \\
\hline $\begin{array}{l}\text { Diastolic blood pressure } \\
(\mathrm{mmHg})\end{array}$ & $76 \pm 4.21$ & $75 \pm 4.18$ & $79 \pm 6.54$ & $77 \pm 3.81$ \\
\hline Pulse rate (beats / min) & $89 \pm 3.96$ & $91 \pm 5.89$ & $89 \pm 4.12$ & $90 \pm 4.83$ \\
\hline
\end{tabular}

Table - 4: Hemodynamic changes encountered during LSCS

\begin{tabular}{|l|l|l|l|l|}
\hline & Group A & Group B & Group C & Group D \\
\hline $\begin{array}{l}\text { SBP }(\mathrm{mmHg}) \\
\text { Minimum }(\mathrm{mmHg})\end{array}$ & 97 & 91 & 111 & 101 \\
\hline Change & 29 & 38 & 10 & 23 \\
\hline \% Change & 23 & 30 & 8 & 19 \\
\hline Time (Min) & 8 & 8 & 10 & 8 \\
\hline MAP, mmHg & & & & \\
\hline Minimum & 72 & 65 & 81 & 74 \\
\hline Change, mmHg & 20 & 27 & 12 & 18 \\
\% Change & 22 & 29 & 13 & 20 \\
\hline Time, (Min) & 8 & 8 & 8 & 10 \\
\hline Hypotension & 7 & 14 & 2 & 0 \\
Bradycardia $[<60 \mathrm{~min}]$ & 3 & 0 & 2 & 0 \\
\hline
\end{tabular}

Group C \& D which received opioids and local anaesthetics together intrathecally had synergistic analgesic effect possible to achieve spinal anaesthesia using otherwise inadequate doses of local anaesthetics with less hypotension.

Table-5: Distribution of Mephentermine doses among 4 groups

\begin{tabular}{|c|c|c|c|c|}
\hline $\begin{array}{l}\text { No. of } \\
\text { Mephentermine } \\
(\mathbf{1} \text { doses = 3 mg) }\end{array}$ & $\begin{array}{l}\text { Group A } \\
{\left[B_{10}+\text { Fentanyl }+\right.} \\
\text { Phenylephrine }] \\
(n=14)\end{array}$ & $\begin{array}{l}\text { Group B } \\
{\left[B_{10}+\text { Fentanyl }\right]} \\
(n=28)\end{array}$ & $\begin{array}{l}\text { Group C } \\
{\left[B_{7}+\text { Fentanyl + Phenylephrine }\right]} \\
(n=4)\end{array}$ & $\begin{array}{l}\text { Group D } \\
{\left[B_{7}+\text { Fentanyl }\right]} \\
(\mathbf{n}=12)\end{array}$ \\
\hline 1 dose & 8 & 10 & 4 & 8 \\
\hline 2 doses & 6 & 12 & - & 4 \\
\hline 3 doses & - & 6 & - & - \\
\hline Total & 14 & 28 & 4 & 12 \\
\hline
\end{tabular}

$\mathrm{n}=$ number of patients

The data was analysed by using SPSS 15.0 version and Microsoft Excel software. Independent sample ' $t$ ' test was used to assess the significance of difference of means between the cases and controls . $\mathrm{P}<0.05$ is considered as significant. 
Table-6: Comparision of Hemodynamic changes between four Groups.

\begin{tabular}{|c|c|c|c|c|c|c|}
\hline & \multicolumn{2}{|c|}{ Group $-A$ and Group-B } & \multicolumn{2}{|c|}{ Group-C and Group-D } & \multicolumn{2}{|c|}{ Group-A and Group-D } \\
\hline & t-value & p-value & t-value & p-value & t-value & p-value \\
\hline $\begin{array}{l}\text { Systolic blood } \\
\text { pressure }(\mathrm{mmHg})\end{array}$ & 1.62 & $>0.05$ & 5,59 & $<0.05^{*}$ & -3.51 & $<0.05^{*}$ \\
\hline $\begin{array}{l}\text { Mean arterial } \\
\text { pressure }(\mathrm{mmHg})\end{array}$ & 2.07 & $<0.05^{*}$ & 5.01 & $<0.05^{*}$ & -3.82 & $<0.05^{*}$ \\
\hline $\begin{array}{l}\text { Diastolic blood } \\
\text { pressure }(\mathrm{mmHg})\end{array}$ & 2.32 & $<0.05^{*}$ & 5.15 & $<0.05^{*}$ & -5.35 & $<0.05^{*}$ \\
\hline Pulse rate (beats / $\mathrm{min}$ ) & 9.5 & $<0.05^{*}$ & -7.2 & $<0.05^{*}$ & 0.7 & $>0.05$ \\
\hline
\end{tabular}

p-value $<0.05 *$ is significant

\section{Discussion}

This randomized study was conducted to show the hemodynamic stability under spinal anaesthesia during ceasarean section deliveries, by reducing the dose of bupivacaine from $10 \mathrm{mg}$ to $7 \mathrm{mg}$. Most of the pregnant women in our maternity ward, coming for elective caesarean sections are less than $160 \mathrm{~cm}$ of height and below $65 \mathrm{kgs}$ of weight so these pregnant women may not require the traditional dose (10 $\mathrm{mg}$ of bupivacaine) which has been advocated since long time and is the established practice (Table-1).

So an attempt has been made to study the level of sensory block, effectiveness of motor blockade (Table-2) and recovery by using low dose bupivacaine $(7 \mathrm{mg}$ ) along with fentanyl, with or without low dose phenylephrine infusion.

Marc Vande velde et. al [5] studied the dose dependent effects of hyperbaric bupivacaine on maternal hemodynamics and showed that small dose of bupivacaine with fentanyl better preserves hemodynamic stability resulting in equally effective anaesthesia.

To prevent hemodynamic instability in most of the previous studies recorded blood pressure non-invasively at 1-2 minutes interval or even less frequently [6-10].

Tejwani et. al [11] study showed that opioids and local anaesthetics administred together intrathecally had synergistic analgesic effect possible to achieve spinal anaesthesia using otherwise inadequate doses of local anaesthetics with less hypotension (Table-4). The first study with continuous invasive monitoring in healthy pregnant women was done by Langestear et al [12].

During caesarean sections phenylephrine maintains maternal systolic blood pressure at baseline and is associated with low incidence of fetal acidosis than that of ephedrine proven by cooper et al $[13,14,15]$.
The hemodynamic curves depicted clearly shows that there is a maximum fall of SBP and MAP around 6-12 minutes after induction of spinal anaesthesia in all groups of pregnant women (Table-3). Group B pregnant women who received high dose bupivacaine $10 \mathrm{mg}$ with $25 \mathrm{mcg}$ fentanyl without phenylephrine have resulted in maximum fall of SBP and MAP (B-10 mg without phenylephrine $70 \%$ ). It is minimal in group $\mathrm{C}$ (B-7mg with phenylephrine $-10 \%$ ).

The mean pulse rate was little lower in case of pregnant women who received phenylephrine than in pregnant women who does not receive phenylephrine. This was same in high dose and low dose bupivacaine groups.

This shows a low dose phenylephrine infusion produce better hemodynamic stability and maintains the pulse rate nearer to baseline which is in correlation with studies of Anna Lee et.al $[15,16]$.

Level of sensory blockade and onset of motor blockade were almost similar in all pregnant women in all groupswith average $\mathrm{T} 4\left[\mathrm{~T}_{3}-\mathrm{T}_{6}\right]$ in all groups. So, we indicates low dose bupivacaine group pregnant women can be made ambulatory at the earliest and also had better hemodynamic stabilty.[17] Lowering the dose of spinal anesthetic is associated with reduced incidence of maternal hypotension, requirement of vasopressors and episodes of nausea or vomiting.[18-20] (Table-6) Roofthooft and Van de Velde reported that using $6.5 \mathrm{mg}$ with sufenatnil as a part of combined spinal epidural (CSE) technique, but take more time [20].

It is successful use of a low dose with efficient anesthesia and minimal incidence of hypotension.[21-25] Owing to the risk of failed intubation and hemodynamic responses to intubation, GA is hazardous in this population and should be reserved for women for whom neuraxial anesthesia is contraindicated [26]. 


\section{Conclusion}

The result shows that, keeping in view of the average height and weight of pregnant women who are coming for LSCS, they just need a minimal dose of hyperbaric bupivacaine along with of fentanyl for adequate level and degree of block, maintaining better hemodynamic stability if it is added with continuous infusion of low dose phenylephrine.

\section{Funding: Nil \\ Conflict of interest: Nil \\ Permission from IRB: Yes}

\section{References}

1. Ben-David B, Solomon E, Levin H, Admoni H, Goldik $Z$. Intrathecal fentanyl with small dose bupivacaine, better anesthesia without prolonging recovery. Anesth analg. 1997 Sep;85(3):560-5.

2. Chu CC, Shu SS, Lin SM, Chu NW, Leu YK, Tsai SK, Lee TY. The effect of intrathecal bupivacaine with combined fentanyl in cesarean section. Acta Anaesthesiol Sin.1995 Sep;33(3):149-54.

3. Dahlgren G, Hultstrand C, Jakobsson J, Norman M, Eriksson EW, Martin H. Intrathecal sufentanil, fentanyl, or placebo added to bupivacaine for cesarean section. Anesth Analg.1997 Dec;85(6):1288-93.

4. Hamber EA, Viscomi CM. Intrathecal lipophilic opioids as adjuncts to surgical spinal anesthesia. Reg Anesth pain Med. 1999 May-Jun.24(3):255-63.

5. Van de Velde M, Van Schoubroeck D, Jani J, Teunkens A, Missant C, Deprest J. Combined spinal-epidural anesthesia for cesarean delivery: dose dependent effects of hyperbaric bupivacaine on maternal hemodynamics. Anesth Analg. 2006 Jul;103(1):187 - 90.

6. Langesaeter E, Rosseland LA, Stubhuag A. Continuous invasive blood pressure and cardiac output monitoring during cesarean delivery: a randomized, double-blind comparison of low-dose versus high-dose spinal anesthesia with intravenous phenylephrine or placebo infusion. Anesthesiology. 2008 Nov;109(5):856-63.

7. Ngan Kee WD, Khaw KS, Ng FF, Lee BB: Prophyactic phenylephrine infusion for preventing hypotension during Anesthesia for cesarean Delivery. Anesth Analg. 2004Mar;98(3):815 - 21 .

8. Aya AG, Mangin R, Vialles N, Ferrer JM, Robert C, Ripart J, de La Coussaye JE. Patients with severe preeclampsia experience less hypotension during spinal anesthesia for elective cesarean delivery than healthy parturients: A prospective cohort comparison. Anesth Analg. 2003 Sep;97(3):867-72.

9. Aya AG, Vialles N, Tanoubi I, Mangin R, Ferrer JM, Robert C, Ripart J, de La Coussaye JE. Spinal anesthesiainduced hypotension: a risk comparison between patients with severe preeclampsia and healthy women undergoing preterm cesarean delivery. Anesth Analg. 2005 Sep;101 (3) : 869-75.

10. Visalyaputra S, Rodanant $\mathrm{O}$, Somboonviboon W, Tantivitayatan K, Thienthong S, Saengchote W. Spinal versus epidural anesthesia for caesarean delivery in severe preeclampsia: A prospective randomized, multicentre study. Anesth Analg 2005 Sep;101(3):862-8.

11. Tejwani GA, Rattan AK, McDonald JS. Role of spinal opioid receptors in the antinociceptive interactions between intrathecal morphine and bupivacaine. Anesth Analg. 1992 May;74(5):726-34.

12. Langesater E, Rosseland LA, Stubhaug A. Continuous invasive blood pressure and cardiac output monitoring during cesarean delivery: A randomized, double-blind comparison of low-dose versus high-dose spinal anesthesia with intravenous phenylephrine or placebo infusion. Anesthesiology. 2008 Nov;109(5):856-63.

13. Cooper DW, Jeyaraj L, Hynd R, Thompson R, Meek T, Ryall DM, Kokri MS. Evidence that intravenous vasopressors can affect rostral spread of spinal anaesthesia in pregnancy. Anaesthesiology. 2004 Jul;101(1):28-33.

14. Lee A, Ngan Kee WD, Gin T. A quantitative systematic review of randomized controlled trials of ephedrine versus phenylephrine for the management of hypotension during spinal anesthesia for cesarean delivery. Anesth Analg. 2002 Dec; 94(4):920-6.

15. Cooper DW, Carpenter M, Mowbray P, Desira WR, Ryall DM,Kokri MS. Fetal and maternal effects of phenylephrine and ephedrine during spinal anesthesia for cesarean delivery.Anesthesiology.2002Dec;97(6):1582-90

16. Cooper DW, Carpenter M, Mowbray P, Desira WR, Ryall DM, Kokri MS. Fetal and maternal effects of phenylephrine and ephedrine during spinal anesthesia for cesareandelivery.Anesthesiology.2002Dec;9796):1582-90

17. Jain K, Grover VK, Mahajan R, Batra YK. Effects of varying doses of fentanyl with low dose spinal bupivacaine for caesarean delivery in patients with pregnancy induced hypertension. Int J Obstet Anesth. 2004 Oct;13(4):215-20.

18. Ramanathan J, Vaddadi AK, Arheart KL. Combined spinal and epidural anesthesia with low doses of intrathecal bupivacaine in women with severe preeclampsia: A preliminary report. Reg Anesth Pain Med. 2001 Jan;26(1):46-51.

19. McNaught AF, Stocks GM. Epidural volume extension and low-dose sequential combined spinalepidural blockade: two ways to reduce spinal dose requirement for caesarean section. Int J Obstet Anesth. 2007 Oct;16(4):346-53.

20. Teoh WH, Sia AT. Ultra-low dose combined spinalepidural anesthesia for Caesarean section in severe preeclampsia. Anaesthesia. 2006 May;61(5):511-2. 
21. Roofthooft E, Van de Velde M. Low-dose spinal anaesthesia for Caesarea section to prevent spinal-induced hypotension. Curr Opin Anaesthesiol. 2008 Jun;21(3):259-62.

22. Birbbach DJ, Browne IM. Anesthesia of Obstretics In: Miller RD, Eriksson LI, Fleisher LA, Wiener-Kronish JP, Young WL. editors. Miller's Anesthesia. 7th ed. USA: Churchill-Livingston Elsevier; 2010:2203-40.

23. Hanley JA, Lippman-Hand A. If nothing goes wrong, is everything all right? Interpreting zero numerators. JAMA 1983 Apr 1;249(13):1743-5.
24. Choi DH, Ahn HJ, Kim JA. Combined low-dose spinal-epidural anesthesia versus single shot spinal anesthesia for elective cesarean delivery. Int $\mathrm{J}$ Obstet Anesth. 2006 Jan;15(1):13-7.

25. Van de Velde M, Van Schoubroeck D, Jani J, Teunkens A, Missant C, Deprest J. Combined spinal epidural anesthesia for cesarean delivery: dose dependent effects of hyperbaric bupivacaine on maternal hemodynamics. Anesth Analg. 2006 Jul;103(1):187-90.

26. Gogarten W. Preclampsia and anesthesia. Curr Opin Anesthesiol. 2009 Jun;22(3):347-51.

\section{How to cite this article?}

Sivaram A, Govardhani Y, Varaprasad U S S A. A comparative study of low dose Bupivacaine vs high dose Bupivacaine along with Fentanyl and Phenylephrine on Pregnant women undergoing elective Caesarean Section under Spinal Anesthesia. Int J Med Res Rev 2014;2(2):124-129. doi:10.17511/ijmrr.2014.i02.10. 